\title{
Improvement of Salt Tolerance in Vicia faba (L.) Plants by Exogenous Application of Polyamines
}

\author{
A. H. A. Mahdi \\ Agronomy Department, Faculty of Agriculture, Fayoum \\ University, Fayoum, Egypt.
}

\begin{abstract}
SALINITY stress causes physiological drought and disturbances in plant physiology that lead to a reduction in plant growth. To search about an effective method to increase salt tolerance of Vicia faba (L.) plants, the effect of soaking the seeds in spermidine (Spd; $1.5 \mathrm{mM}$ ) or spermine (Spm; $1.5 \mathrm{mM})$ on growth, drought tolerance, contents of free proline, total soluble sugars, starch, endogenous Spm and Spd, and antioxidant system in plants grown under salt stress of a saline calcareous soil was studied. Spm or Spd alleviated the adverse effects of salt stress to convergent degrees. Soaking faba bean seeds in either Spd or Spm increased all plant growth characteristics and the activities of antioxidant enzymes compared to the control (seeds soaked in distilled water). In addition, soaking seeds in either polyamine significantly increased membrane stability index, relative water content, contents of ascorbic acid, glutathione, endogenous Spm and Spd. All these improved parameters reflected in enhanced yield and its components. In contrast, electrolyte leakage, concentrations of protein, starch, malondialdehyde and hydrogen peroxide were reduced compared to the control. Data of the present study also show that, the variety Giza 429 exhibited better results than the variety Giza 40, concluding that Giza 429 was more salt-tolerant compared to Giza 40. These results are important as the potential of Spd or Spm to mitigate the deleterious effects of soil salinity stress offer an opportunity to increase the faba bean tolerance to growth under saline conditions.
\end{abstract}

Keywords: Antioxidant system, Salinity, Spermidine, Spermine, Faba bean varieties.

Salinity stress is one of the most serious abiotic stress factors that limit crop productivity by reduction in plant growth and development (Parida \& Das, 2005). Salt stress imposes two restrictions on plants; the hyperosmotic impact because of lower soil water potential and the hyperionic impact due to direct toxicity and antagonism of ions, which cause nutrient imbalance (Neumann, 1997). It affects plant physiology via osmotic and ionic stress at both the whole plant and cellular level. It generates a physiological drought (or osmotic stress) by affecting the water relations of the plant (Munns, 2002). The accumulation of toxic salt concentrations in the leaf apoplasm leads to dehydration, loss of turgor, the death of cells and tissues and consequently the whole plant. Photosynthesis is one of the most severely affected processes during salinity stress (Sudhir \& Murthy, 2004) through the decreased level of chlorophyll (Rady, 2011), the 
inhibition of various enzymes, including RuBisCO (Soussi et al., 1998), and the closure of stomata, thereby decreasing the leaf intercellular $\mathrm{CO}_{2}$ pressure (Bethkey \& Drew, 1992). These altered processes lead to poor plant growth and productivity. However, lipid peroxidation and the antioxidant system of plants (e.g., antioxidant enzymes and non-enzymatic low molecular weight antioxidants) have been reported to be stimulated by salt stress (Sairam et al., 2005; Rady, 2011 and Rady et al., 2013).

Polyamines (PAs) such as spermine (Spm) and spermidine (Spd) are plant growth regulators, low-molecular-weight polycations ubiquities in all living organisms (Galston et al., 1997). The relationships between PAs and environmental stresses have been studied (Pandolfi et al., 2010 and An et al., 2012). Biosynthesis of PAs has been reported as an integral part of plant's response to salt stress (Alca'zar et al., 2010). The increases in biosynthesis of PAs might protect the plants from salt stress damages by scavenging the harmful free radicals, maintaining the membrane stability and cellular structures, keeping the balance of cation-anion (Bouchereau et al., 1999), regulating the ion channels and inducing the ATP synthesis (Lopatin et al., 1994). Few studies on the exogenous application of free PAs have been focused on alleviating the negative effects of salt stress (Verma \& Mishra, 2005; Iqbal et al., 2006; Duan et al., 2008 and Amri et al., 2011), although the contribution of free PAs in osmotic adjustment and the internal changes of these compounds within the plant tissue under the salt stress has been confirmed (Janicka-Russak et al., 2010).

Faba beans (Vicia faba L.) are considered popular legume foods consumed worldwide as an important protein source for human and animal nutrition. Seeds of faba beans are rich in carbohydrates, proteins and minerals (Broughton et al., 2003). Saxena et al. (1993) reported that there is a considerable variability in salinity tolerance among legumes, however, others considered them either sensitive or only moderately tolerant to salinity (Subbarao \& Johansen, 1993). $V$. faba plants are proved to be moderately sensitive legume to salinity (Delgado et al., 1994), exhibiting a reduction in plant growth up to $50 \%$ under $6.7 \mathrm{dS} \mathrm{m}^{-1}$ salinity (Mass \& Hoffman, 1977). Breeding for salt tolerance in crops has usually been limited by the lack of reliable traits for selection (Noble \& Rogers, 1992). It is necessary to determine differences in resistance mechanisms between the genotypes and to incorporate characters that improve tolerance into reasonably high-yielding backgrounds. The differences in the salt tolerance of faba bean genotypes were observed by Gaballah \& Gomaa (2005).

Nowadays in Egypt, there is a tendency to expand the cultivated area for many crops, including faba beans in newly-reclaimed soils, although most of these soils are affected by salinity, which is considered a global real problem that requires urgent solutions. Despite attempts carried out to identify varieties of faba bean plants through experiments to be grown in the newly-reclaimed saline soils, there is only a limited number of varieties that have been developed with

Egypt. J. Agron. 38, No. 1 (2016) 
improved tolerance. Therefore, the present study was designed to examine the influence of PAs (e.g., Spm and Spd), applied by seed soaking, on seedling growth, cell membrane disorders, drought tolerance, osmoprotectant contents and the activities of the antioxidant system in two varieties of faba bean plants grown on a saline calcareous soil $(\mathrm{ECe}=8.48-8.55)$.

\section{Materials and Methods}

Plant material, growing conditions, experimental design and treatments

Two field experiments were conducted in two successive seasons (2013/2014 and 2014/2015) at the Experimental Farm of Faculty of Agriculture, Fayoum University, Southeast Fayoum $\left(29^{\circ} 17^{\prime} \mathrm{N} ; 30^{\circ} 53^{\prime} \mathrm{E}\right)$, Egypt. The daily temperatures averaged $21.2^{\circ} \pm 2.6^{\circ} \mathrm{C}$ and $22.1^{\circ} \pm 2.8^{\circ} \mathrm{C}$, and the daily relative humidity averaged $58.4 \pm 5.1 \%$ and $60 \pm 4.9 \%$ in both seasons, respectively. Healthy seeds of two varieties (i.e., Giza 40 and Giza 429) of faba bean (V. faba L.) were sown after soaking treatments on 23 and 20 October 2013 and 2014, respectively. Seeds were obtained from Field Crop Research Institute, Agricultural Research Centre, Giza, Egypt. Seeds were selected for uniformity by choosing those of equal size and of the same color and were washed with distilled water, sterilized in $1 \%(\mathrm{v} / \mathrm{v})$ sodium hypochlorite for approximately 2 min, washed thoroughly again with distilled water, and left to dry at room temperature. Seeds were subjected to soaking treatments in spermine (Spm; 1.5 $\mathrm{mM}$ ), spermidine (Spd; $1.5 \mathrm{mM}$ ) or distilled water (as a control) for $4 \mathrm{~h}$, and then soaked seeds were air-dried again at room temperature overnight. Uniform, airdried faba bean seeds were sown in hills spaced $20-25 \mathrm{~cm}$ apart, in rows spaced $70 \mathrm{~cm}$ apart in $3.0 \mathrm{~m} \times 3.5 \mathrm{~m}$ plots, using an equivalent of $120 \mathrm{~kg}$ seed ha ${ }^{-1}$ to generate the recommended planting density. Thinning was done before the first irrigation to remain two plants per hill. During soil preparation and plant growth, the soil was supplemented with the full dose of NPK fertilizer according to the recommendations of the Ministry of Agriculture and Land Reclamation [i.e., 450 $\mathrm{kg} \mathrm{ha}^{-1}$ calcium superphosphate $\left(15.5 \% \mathrm{P}_{2} \mathrm{O}_{5}\right), 250 \mathrm{~kg} \mathrm{ha}^{-1}$ ammonium sulfate $(20.5 \% \mathrm{~N})$, and $120 \mathrm{~kg} \mathrm{ha}^{-1}$ potassiumsulfate $\left.\left(48 \% \mathrm{~K}_{2} \mathrm{O}\right)\right]$. Irrigation water was added to $100 \%$ of the reference crop evapotranspiration (ETo), values from the Fayoum Meteo Station. Seven irrigations were applied in each season, with total water rates of about $2800 \mathrm{~m}^{3} \mathrm{ha}^{-1}$ in each growing season. All other recommended agricultural practices were followed as recommended by the Ministry of Agriculture and Land Reclamation.

One experimental site was chosen for each season in the same location and the analysis of soil samples were conducted according to Klute (1986) and Page et al. (1982). Data of soil analyses are presented in Table 1. Based on the $\mathrm{EC}_{\mathrm{e}}$ values, soil was classed as being strongly saline according to Dahnke \& Whitney (1988). The experimental design used was split plot arrangement in randomized complete block, with one level of each of Spm or Spd (1.5 mM for each), with three replicate plots. 
TABLE 1. Some of the physical and chemical properties of the selected soil before planting in two seasons.

\begin{tabular}{|c|c|c|}
\hline Properties & $2013 / 2014$ & $2014 / 2015$ \\
\hline 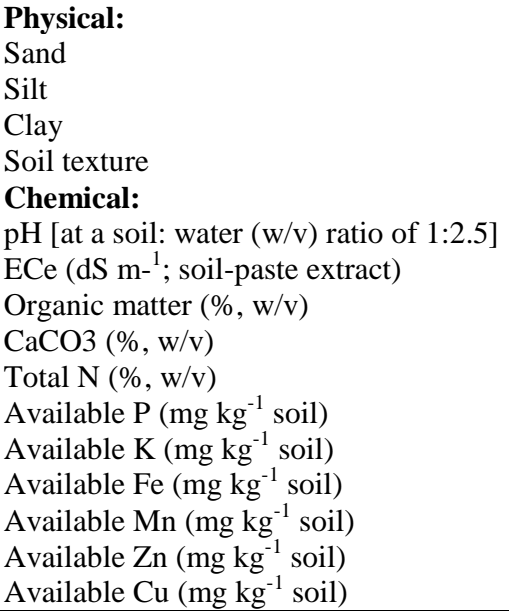 & $\begin{array}{c}76.8 \\
12.5 \\
10.7 \\
\text { Sandy loam } \\
\\
7.66 \\
8.48 \\
0.94 \\
6.86 \\
0.074 \\
8.57 \\
190 \\
6.30 \\
2.35 \\
0.95 \\
0.43 \\
\end{array}$ & $\begin{array}{c}75.3 \\
13.5 \\
11.2 \\
\text { Sandy loam } \\
\\
7.72 \\
8.55 \\
0.92 \\
6.79 \\
0.070 \\
8.39 \\
185 \\
5.99 \\
2.29 \\
0.93 \\
0.50 \\
\end{array}$ \\
\hline
\end{tabular}

Plant growth and yield measurements

From each experimental plot, fifty-day-old plants $(n=9)$ were carefully removed and dipped in a bucket of water. Plants were shaken gently to remove all adhering soil particles and the lengths of their shoots were measured using a meter scale. Numbers of leaves plants ${ }^{-1}$ were counted. The shoots of plants were weighed to record their fresh weights. They were then placed in an oven at $70{ }^{\circ} \mathrm{C}$ until constant weight and the dry weights were recorded. Using a graph sheet, leaf areas were measured manually where the squares covered by the leaf were counted. At the end of each experiment (4 and 2 April 2014 and 2015, respectively), yield and its components (i.e., number of dry pods plant ${ }^{-1}$, 100seed weight, dry seed yield plant ${ }^{-1}$ and dry seed yield hectare ${ }^{-1}$ ) were determined.

Determination of membrane stability index, electrolyte leakage, and relative water content

Membrane stability index (MSI) was estimated as described by Rady (2011) using duplicate $0.2 \mathrm{~g}$ samples of leaf blade. Samples were placed in test tubes containing $10 \mathrm{ml}$ of double-distilled water. One sample was heated at $40{ }^{\circ} \mathrm{C}$ in a water bath for $30 \mathrm{~min}$ and the electrical conductivity of the solution was recorded using a conductivity bridge $\left(\mathrm{EC}_{1}\right)$. The second sample was boiled at $100{ }^{\circ} \mathrm{C}$ for $10 \mathrm{~min}$, and the conductivity was measured $\left(\mathrm{EC}_{2}\right)$. The MSI was calculated using the formula:

$$
\operatorname{MSI}(\%)=\left[1-\left(\mathrm{EC}_{1} / \mathrm{EC}_{2}\right)\right] \times 100
$$

The total leakage of inorganic ions from leaves was determined using the method of Sullivan \& Ross (1979). Twenty leaf discs were placed in a boiling tube containing $10 \mathrm{ml}$ deionized water and the electrical conductivity $\left(\mathrm{EC}_{1}\right)$ was

Egypt. J. Agron. 38, No. 1 (2016) 
recorded. The contents were then heated to $45-55^{\circ} \mathrm{C}$ for 30 min each in a water bath and the electrical conductivity $\left(\mathrm{EC}_{2}\right)$ was recorded. The sample was boiled at $100{ }^{\circ} \mathrm{C}$ for $10 \mathrm{~min}$ and the electrical conductivity $\left(\mathrm{EC}_{3}\right)$ was recorded. Electrolyte leakage was calculated using the formula:

$$
\text { Electrolyte leakage }(\%)=\left[\left(\mathrm{EC}_{2}-\mathrm{EC}_{1}\right) / \mathrm{EC}_{3}\right] \times 100
$$

Fresh $2 \mathrm{~cm}$-diameter fully-expanded leaf discs, excluding the midrib, were used to determine the relative water content (RWC). The discs were weighed (fresh mass; FM) and immediately floated on double-distilled water in Petri dishes for $24 \mathrm{~h}$, in the dark, to saturate them with water. Any adhering water was blotted dry and the turgid mass (TM) was measured. The dry mass (DM) was recorded after dehydrating the discs at $70{ }^{\circ} \mathrm{C}$ for $48 \mathrm{~h}$. The RWC was then calculated using the formula (Hayat et al., 2007):

$$
\mathrm{RWC}(\%)=[(\mathrm{FM}-\mathrm{DM}) /(\mathrm{TM}-\mathrm{DM})] \times 100
$$

\section{Determination of free proline, total soluble sugars and starch concentrations}

Proline concentration in fresh leaves was measured by the rapid colorimetric method of Bates et al. (1973). Each sample of $0.2 \mathrm{~g}$ fresh leaf tissue was extracted by grinding in $10 \mathrm{ml}$ of $3 \%(\mathrm{v} / \mathrm{v})$ sulphosalicylic acid. The mixture was then centrifuged at $10,000 \times g$ for $10 \mathrm{~min}$. Two $\mathrm{ml}$ of the supernatant was added to a test-tube and $2 \mathrm{ml}$ of freshly prepared acid-ninhydrin solution was then added. Each tube was incubated in a water bath at $90{ }^{\circ} \mathrm{C}$ for $30 \mathrm{~min}$. The reaction was terminated in an ice-bath. Each reaction mixture was extracted with $5 \mathrm{ml}$ of toluene and vortex mixed for $15 \mathrm{~s}$. The tubes were allowed to stand for $\geq 20 \mathrm{~min}$ in dark at room temperature to allow separation of the toluene and aqueous phases. Each toluene phase was then collected carefully into a test tube and the absorbance of the toluene fraction was read at $520 \mathrm{~nm}$. The proline concentration in each sample was determined using a standard curve of analytical-grade proline.

Total soluble sugars were extracted and determined according to Irigoyen et al. (1992). A $0.2 \mathrm{~g}$ sample of fresh leaves was homogenized in $10 \mathrm{ml}$ of $96 \%(\mathrm{v} / \mathrm{v})$ ethanol and washed with $5 \mathrm{ml} \mathrm{70 \%} \mathrm{(v/v)} \mathrm{ethanol.} \mathrm{The} \mathrm{extract} \mathrm{was} \mathrm{centrifuged} \mathrm{at}$ $3,500 \times g$ for $10 \mathrm{~min}$ and the supernatant was stored at $4{ }^{\circ} \mathrm{C}$ for measurement. Total soluble sugars concentrations were determined by reacting $0.1 \mathrm{ml}$ of the ethanolic extract with $3 \mathrm{ml}$ of freshly prepared anthrone reagent [150 mg anthrone plus $100 \mathrm{ml}$ of $72 \%(\mathrm{v} / \mathrm{v})$ sulphuric acid] and placed in a boiling water bath for $10 \mathrm{~min}$. After cooling, the absorbance of the mixture was recorded at $625 \mathrm{~nm}$ using a Bausch and Lomb-2000 Spectronic Spectrophotometer.

The extraction and measuring of starch concentration, using fresh leaf sample $(0.1 \mathrm{~g})$ that was homogenized in $80 \%$ ethanol, was conducted according to the method of Hedge \& Hofreiter (1962). The absorbance was measured at $630 \mathrm{~nm}$. Glucose was used as a standard solution. 
Determination of the extent of lipid peroxidation, and the concentrations of ascorbic acid (AsA), glutathione $(G S H)$, hydrogen peroxide $\left(\mathrm{H}_{2} \mathrm{O}_{2}\right)$, spermine (Spm), spermidine ( $\mathrm{Spd}$ ) and shoot sodium $\left(\mathrm{Na}^{+}\right)$concentration

Lipid peroxidation was measured in terms of malondialdehyde (MDA) concentration, a product of lipid peroxidation according to Hodges et al. (1999). Each $0.5 \mathrm{~g}$ sample of fresh leaf tissue was homogenized in a mortar with $10 \mathrm{ml}$ of $80 \%(\mathrm{v} / \mathrm{v})$ ethanol. The homogenate was then centrifuged at $3,000 \times g$ for 10 min at $4{ }^{\circ} \mathrm{C}$., and the pellet was extracted twice with the same solvent. The supernatants were pooled and $1.0 \mathrm{ml}$ was added to a test-tube containing an equal volume of $20 \%(\mathrm{w} / \mathrm{v})$ trichloroacetic acid (TCA), $0.01 \%(\mathrm{v} / \mathrm{v})$ butylated hydroxyl-toluene, and $0.65 \%(\mathrm{v} / \mathrm{v})$ thiobarbituric acid. All samples were heated at $95{ }^{\circ} \mathrm{C}$ for $25 \mathrm{~min}$ and cooled to room temperature. The absorbance of each sample was recorded at 440, 532, and $600 \mathrm{~nm}$. The formula given by Hodges et al. (1999) was used to calculate the level of lipid peroxidation in nmol MDA ml${ }^{-1}$.

The AsA concentration in faba bean leaves was determined using the method of Mukherjee \& Choudhuri (1983). Each $0.5 \mathrm{~g}$ fresh leaf sample was extracted with $10 \mathrm{ml}$ of $6 \%(\mathrm{w} / \mathrm{v})$ TCA. The extract was mixed with $2 \mathrm{ml}$ of $2 \%(\mathrm{w} / \mathrm{v})$ dinitrophenylhydrazine (in acidic medium) followed by the addition of one drop of $10 \%(\mathrm{w} / \mathrm{v})$ thiourea in $70 \%(\mathrm{v} / \mathrm{v})$ ethanol. The mixture was then boiled for 15 min in a water bath and, after cooling at room temperature, $5 \mathrm{ml}$ of $80 \%(\mathrm{v} / \mathrm{v})$ $\mathrm{H}_{2} \mathrm{SO}_{4}$ was added at $0{ }^{\circ} \mathrm{C}$. The absorbance was recorded at $530 \mathrm{~nm}$. The concentration of AsA was calculated from a standard curve plotted with known concentrations of AsA.

The GSH concentration was determined using the method described by Griffth (1980). Fresh leaf tissue (50 mg) was homogenized in $2 \mathrm{ml}$ of $2 \%$ (v/v) metaphosphoric acid and centrifuged at $17,000 \times g$ for $10 \mathrm{~min}$. Aliquots of the supernatant were neutralized by adding $0.6 \mathrm{ml}$ of $10 \%$ (w/v) sodium citrate to 0.9 $\mathrm{ml}$ of the extract. Each $1.0 \mathrm{ml}$ assay contained $700 \mu \mathrm{NADPH}(0.3 \mathrm{mM}), 100 \mu \mathrm{l}$ of $6 \mathrm{mM}$ 5,5'-dithiobis-2-nitrobenzoic acid, $100 \mu \mathrm{l}$ distilled water, and $100 \mu \mathrm{l}$ of extract was stabilized at $25^{\circ} \mathrm{C}$ for $3-4 \mathrm{~min}$. Then $10 \mu \mathrm{l}$ of 50 units ml ${ }^{-1} \mathrm{GSH}$ reductase was added and the absorbance was recorded at $412 \mathrm{~nm}$. GSH concentration was calculated from a standard curve.

The $\mathrm{H}_{2} \mathrm{O}_{2}$ concentration was assessed using frozen leaf samples (Velikova et al., 2000). Samples (1.0 g) were ground in an ice bath with $5 \mathrm{ml} 0.1 \%(\mathrm{w} / \mathrm{v})$ trichloroacetic acid. The homogenates were centrifuged at $12,000 \times g$ for $15 \mathrm{~min}$. Then, $0.5 \mathrm{ml}$ of the supernatant was added to $0.5 \mathrm{ml}$ of potassium phosphate buffer $(10 \mathrm{mM}, \mathrm{pH}$ 7). The absorbance of the supernatant was measured at $390 \mathrm{~nm}$.

The extraction and analysis of Spm and Spd were conducted according to Kim et al. (2002). Fresh leaf pieces were collected and weighed $(0.05 \mathrm{~g})$, then homogenized with a glass homogenizer at $4{ }^{\circ} \mathrm{C}$ in the presence of $0.4 \mathrm{ml} 5 \%$ (v/v) $\mathrm{HClO}_{4}$. The homogenates were centrifuged at $15,000 \times \mathrm{g}$ for $20 \mathrm{~min}$ at $4^{\circ} \mathrm{C}$, then supernatants collected and dansylated. The supernatants were mixed with $0.5 \%(\mathrm{w} / \mathrm{v})$ dansyl chloride $(\mathrm{DsCl})$ saturated with $\mathrm{Na}_{2} \mathrm{CO}_{3}$ in a ratio of

Egypt. J. Agron. 38, No. 1 (2016) 
$1: 2: 1(\mathrm{v} / \mathrm{v} / \mathrm{v})$ and incubated in the dark at $25{ }^{\circ} \mathrm{C}$ for $18 \mathrm{~h}$. L-proline $(100 \mathrm{mg}$ $\mathrm{ml}^{-1}$ ) was then added to the mixtures in a ratio of $1: 8(\mathrm{v} / \mathrm{v})$ and incubated for 30 min. To extract Spm and Spd, benzene was added and the mixture was stirred vigorously for $30 \mathrm{~s}$. The extracted solutions of Spm and Spd were then subjected to thin-layer chromatography (TLC). Uniform amounts of Spm and Spd extracts $(50 \mathrm{ml}$ for each) and their standard solutions were applied at several points on preheated silica gel plates. The TLC plates were developed in a chamber containing chloroform and trimethylamine in a ratio of 100:9 (v/v). The Spm-like and Spd-like compounds were identified by the same Rf to that of Spm and Spd standards. After confirmation of the location of Spm and Spd with a UV light source, Spm and Spd containing silica spots were collected and eluted with $4 \mathrm{ml}$ ethyl acetate. The fluorescence of these solutions was measured with a UV-fluorescence spectrophotometer (Model F-3010, Hitachi Co., Tokyo, Japan) at $359 \mathrm{~nm}$ exciting and $495 \mathrm{~nm}$ emission wavelengths. To prepare the standard curves, Spm and Spd at different weights were dissolved in $5 \%(\mathrm{v} / \mathrm{v}) \mathrm{HClO}_{4}$. The Spm and Spd standards were dansylated, extracted and detected as described above.

For $\mathrm{Na}^{+}$ion determination, shoot samples faba bean plants were extracted in $0.1 \mathrm{~N}$ nitric acid. $\mathrm{Na}^{+}$contents were determined by flame photometry in the samples from green faba bean plants (Taleisnik \& Grunberg, 1994).

\section{Enzyme assays}

Samples of frozen leaves $(1.0 \mathrm{~g})$ were homogenized in $50 \mathrm{mM}$ sodium phosphate buffer [pH 7.8 for superoxide dismutase (SOD), and $\mathrm{pH} 7$ for catalase (CAT)]. The homogenates were centrifuged at $12,000 \times g$ for $20 \mathrm{~min}$ at $4{ }^{\circ} \mathrm{C}$. The supernatants were used to assess the activity of the enzymes. SOD activity was assessed according to the method of Giannopolitis \& Ries (1977). One unit of SOD activity was defined as the amount of enzyme required to inhibit $50 \%$ of the rate of p-nitro blue tetrazolium chloride reduction at $560 \mathrm{~nm}$.

Catalase activity was determined according to the method described by Cakmak \& Marschner (1992). The reaction mixture in a total volume of $2 \mathrm{ml}$ contained sodium phosphate buffer $(25 \mathrm{mM}, \mathrm{pH} 7)$ and $\mathrm{H}_{2} \mathrm{O}_{2}(10 \mathrm{mM})$. The reaction was initiated by the addition of $100 \mu$ l enzyme extract and the activity was assessed by determining the initial rate of disappearance of $\mathrm{H}_{2} \mathrm{O}_{2}$ at $240 \mathrm{~nm}$ ( $\varepsilon: 39.4 \mathrm{mM} \mathrm{cm}^{-1}$ ) for $30 \mathrm{~s}$. Samples of $1.0 \mathrm{~g}$ fresh leaves were ground in $5 \mathrm{ml}$ Tris- $\mathrm{HCl}$ buffer $(0.05 \mathrm{M})$. The homogenates were centrifuged at $10,000 \times g$ for $25 \mathrm{~min}$ at $4{ }^{\circ} \mathrm{C}$. The supernatants were used to analyze the protein content (Bradford, 1979) and the activity of peroxidase (POX) and ascorbate peroxidase (APX) enzymes. POX activity was assessed according to Kara \& Mishra (1976). The reaction mixture consisted of $2.5 \mathrm{ml}$ Tris- $\mathrm{HCl}$ buffer $(0.1 \mathrm{M}), 2.5 \mathrm{ml} \mathrm{H}_{2} \mathrm{O}_{2}(5$ $\mathrm{mM}), 2.5 \mathrm{ml}$ pyrogallol $(10 \mathrm{mM})$ and $50 \mu \mathrm{l}$ enzyme extract. $\mathrm{H}_{2} \mathrm{O}_{2}$ dependent oxidation of pyrogallol was followed by a decrease in the absorbance at $425 \mathrm{~nm}$ ( $\varepsilon: 12 \mathrm{mM} \mathrm{cm}^{-1}$ ). APX activity was assessed according to Nakano \& Asada 
(1981). The reaction mixture consisted of $2 \mathrm{ml}$ sodium phosphate buffer $(0.05$ M), $0.2 \mathrm{ml} \mathrm{H}_{2} \mathrm{O}_{2}(3 \%), 0.2 \mathrm{ml}$ ascorbate $(0.05 \mathrm{mM})$ and $0.1 \mathrm{ml}$ enzyme extract. $\mathrm{H}_{2} \mathrm{O}_{2}$ dependent oxidation of ascorbate was followed by a decrease in the absorbance at $290 \mathrm{~nm}\left(\varepsilon: 2.8 \mathrm{mM} \mathrm{cm}^{-1}\right)$, where " $\varepsilon$ " is the molar extinction coefficient.

\section{Statistical analysis}

All data were subjected to analysis of variance (ANOVA) for a split plot arrangement in randomized complete block design, after testing for homogeneity of error variances according to the procedure outlined by Gomez \& Gomez (1984). Combined analysis of data of the two seasons was conducted and significant differences between treatments were compared at $P \leq 0.05$ by Duncan's multiple range test.

\section{Results}

Effect of spermidine (Spd) or spermine (Spm) on growth attributes

For varieties, there are significant increases in growth characteristics (i.e., shoot length, leaves number, leaf area, shoot fresh weight and shoot dry weight) of Giza 429 compared to those of Giza 40. Soaking the seeds of both varieties in $1.5 \mathrm{mM}$ spermidine or $1.5 \mathrm{mM}$ spermine significantly increased all tested growth traits of plants compared to control plants that generated from seeds soaked in distilled water (Table 2). The increases in the above growth characteristics were $73.3,36.6,62.1,102.3$ and $89.4 \%$, respectively for Giza 40, and were 66.3, 34.4, 66.7, 93.9 and $86.5 \%$, respectively for Giza 429 compared to their controls. There are no significant differences between the results obtained from Spd and Spm applications.

Effect of spermidine (Spd) or spermine (Spm) on membrane stability index $(M S I)$, electrolyte leakage (EL) and relative water content $(R W C)$

For varieties, there are no significant differences in RWC and EL between both varieties, while Giza 429 was significantly exceeded Giza 40 for MSI. Plants generated from seeds of both varieties which soaked in $1.5 \mathrm{mM}$ spermidine or $1.5 \mathrm{mM}$ spermine exhibited significant increases in RWC and MSI, while showed significant reduction in EL compared to control plants that generated from seeds soaked in distilled water (Table 3). The increases in the RWC and MSI were 23.7 and 14\%, respectively for Giza 40, and 20.7 and $17.6 \%$, respectively for Giza 429, while the decrease in EL was $38.8 \%$ for Giza 40 and $31.1 \%$ for Giza 429 compared to their controls. There are no significant differences between the results obtained from Spd and Spm applications. 
TABLE 2. Effect of seed soaking in spermidine (Spd; $1.5 \mathrm{mM}$ ) or spermine (Spm; $1.5 \mathrm{mM})$ on shoot length $(\mathrm{cm})$, number of leaves per plant, total leaf area $\left(\mathbf{d m}^{2}\right)$, fresh weight $(\mathrm{FW} ; \mathrm{g})$ and dry weight $(\mathrm{DW} ; \mathrm{g})$ of two varieties of Vicia faba (L.) plants grown in reclaimed-saline calcareous soil (combined data over 2013/2014 and 2014/2015 seasons).

\begin{tabular}{|c|c|c|c|c|c|c|}
\hline \multicolumn{2}{|c|}{ Treatments } & \multirow{2}{*}{$\begin{array}{l}\text { Shoot } \\
\text { length }\end{array}$} & \multirow{2}{*}{$\begin{array}{l}\text { No. of leaves } \\
\text { plant }^{-1}\end{array}$} & \multirow{2}{*}{$\begin{array}{c}\text { Leaf area } \\
\text { plant }^{-1}\end{array}$} & \multirow{2}{*}{ Shoot FW } & \multirow{2}{*}{ Shoot DW } \\
\hline Variety & Polyamine & & & & & \\
\hline \multirow{4}{*}{ Giza 40} & Control $^{* * *}$ & $32.2 \pm 2.5 b^{*}$ & $14.2 \pm 0.5 b$ & $10.3 \pm 1.0 \mathrm{~b}$ & $48.6 \pm 3.4 b$ & $6.6 \pm 0.4 b$ \\
\hline & $\mathrm{Sp}$ & $55.8 \pm 3.3 \mathrm{a}$ & $19.4 \pm 0.7 \mathrm{a}$ & $16.7 \pm 1.5 \mathrm{a}$ & $98.3 \pm 6.2 \mathrm{a}$ & $12.5 \pm 0.7 \mathrm{a}$ \\
\hline & & $53.9 \pm 3.1 \mathrm{a}$ & $18.8 \pm 0.7 \mathrm{a}$ & $16.2 \pm 1.4 \mathrm{a}$ & $94.8=$ & $11.9 \pm 0.6 \mathrm{a}$ \\
\hline & $M$ & $47.3 \pm 3.0 \mathrm{~B}$ & 17.5 & 14.4 & $80.6=$ & $10.3 \pm 0.6 B$ \\
\hline \multirow{4}{*}{429} & Control & $2.6 \mathrm{~b}$ & $15.4 \pm 0.6 b$ & $\pm 1.0 \mathrm{~b}$ & $53.8 \pm 3.7 b$ & $7.4 \pm 0.5 b$ \\
\hline & Spd & $58.7 \pm 3.5 \mathrm{a}$ & $20.7 \pm 0.8 \mathrm{a}$ & $19.0 \pm 1.6 \mathrm{a}$ & $104.3 \pm 6.8 \mathrm{a}$ & $13.8 \pm 0.8 \mathrm{a}$ \\
\hline & Spm & $58.2 \pm 3.4 \mathrm{a}$ & $20.3 \pm 0.8 \mathrm{a}$ & $18.6 \pm 1.6 \mathrm{a}$ & $99.5 \pm 6.3 \mathrm{a}$ & $13.5 \pm 0.8 \mathrm{a}$ \\
\hline & Mean & $50.7 \pm 3.2 \mathrm{~A}$ & $18.8 \pm 0.7 \mathrm{~A}$ & $16.3 \pm 1.4 \mathrm{~A}$ & $85.9 \pm 4.6 A$ & $11.6 \pm 0.7 \mathrm{~A}$ \\
\hline
\end{tabular}

"Mean values $(\mathrm{n}=9)$ in the same column for each trait with the same lower small or upper bold-case letters are not significantly different by Duncan's Multiple Range Test at $\mathrm{P} \leq 0.05$.

${ }^{* *}$ Control $=$ seeds soaked in distilled water.

TABLE 3. Effect of seed soaking in spermidine (Spd; $1.5 \mathrm{mM}$ ) or spermine (Spm; $1.5 \mathrm{mM}$ ) on the membrane stability index (MSI \%), electrolyte leakage (EL \%) and relative water content (RWC \%) of two varieties of Vicia faba (L.) plants grown in reclaimed-saline calcareous soil (combined data over 2013/2014 and 2014/2015 seasons).

\begin{tabular}{|c|c|c|c|c|}
\hline \multicolumn{2}{|c|}{ Treatments } & \multirow{2}{*}{ MSI (\%) } & EL (\%) & \multirow{2}{*}{ RWC (\%) } \\
\cline { 1 - 1 } Variety & Polyamine & & & \\
\hline & Control $^{* * *}$ & $54.2 \pm 2.3 b^{*}$ & $10.40 \pm 0.21 \mathrm{a}$ & $58.2 \pm 3.0 \mathrm{~b}$ \\
Giza 40 & Spd & $61.8 \pm 2.9 \mathrm{a}$ & $6.37 \pm 0.13 \mathrm{~b}$ & $72.0 \pm 4.2 \mathrm{a}$ \\
& Spm & $60.7 \pm 2.7 \mathrm{a}$ & $6.42 \pm 0.14 \mathrm{~b}$ & $70.9 \pm 4.0 \mathrm{a}$ \\
& Mean & $\mathbf{5 8 . 9} \pm \mathbf{2 . 6 B}$ & $\mathbf{7 . 7 3} \pm \mathbf{0 . 1 6 A}$ & $\mathbf{6 7 . 0} \pm \mathbf{3 . 7 A}$ \\
& Control & $56.8 \pm 2.7 \mathrm{~b}$ & $9.06 \pm 0.37 \mathrm{a}$ & $61.3 \pm 2.1 \mathrm{~b}$ \\
Giza 429 & Spd & $66.8 \pm 3.6 \mathrm{a}$ & $6.24 \pm 0.23 \mathrm{~b}$ & $74.0 \pm 3.6 \mathrm{a}$ \\
& Spm & $65.5 \pm 3.4 \mathrm{a}$ & $6.38 \pm 0.25 \mathrm{~b}$ & $71.9 \pm 3.3 \mathrm{a}$ \\
& Mean & $\mathbf{6 3 . 0} \pm \mathbf{3 . 2 A}$ & $\mathbf{7 . 2 3} \pm \mathbf{0 . 2 8}$ & $\mathbf{6 9 . 1} \pm \mathbf{3 . 0 A}$ \\
\hline
\end{tabular}

"Mean values $(n=9)$ in the same column for each trait with the same lower small or upper bold-case letters are not significantly different by Duncan's Multiple Range Test at $\mathrm{P} \leq 0.05$.

${ }^{*}$ Control $=$ seeds soaked in distilled water.

Effect of spermidine (Spd) or spermine (Spm) on protein, free proline, sugars and starch concentrations

For varieties, there are no significant differences in protein and starch between both varieties, but Giza 429 was significantly exceeded Giza 40 for free proline and total soluble sugars. Plants produced from seeds of both varieties which soaked in $1.5 \mathrm{mM}$ spermidine or $1.5 \mathrm{mM}$ spermine showed significant increases in free proline and total soluble sugars, while showed significant decreases in protein and starch compared to control plants that produced from seeds soaked in distilled water (Table 4). The increases in the free proline and 
total soluble sugars were 44.8 and $42.4 \%$, respectively for Giza 40, and 39.2 and $40 \%$, respectively for Giza 429 , while the decreases in protein and starch were 17.9 and $26.5 \%$, respectively for Giza 40 and 20.8 and $35.5 \%$, respectively for Giza 429 compared to their controls. There are no significant differences between the results obtained from Spd and Spm applications.

TABLE 4. Effect of seed soaking in spermidine (Spd; $1.5 \mathrm{mM})$ or spermine (Spm; $1.5 \mathrm{mM})$ on leaf contents of protein $\left(\mathrm{mg} \mathrm{g}^{-1} \mathrm{FW}\right)$, free proline $\left(\mu \mathrm{g} \mathrm{g}^{-1} \mathrm{FW}\right)$, total soluble sugar $\left(\mathrm{mg} \mathrm{g}^{-1} \mathrm{FW}\right)$ and starch $\left(\mathrm{mg} \mathrm{g}^{-1} \mathrm{FW}\right)$ of two varieties of Vicia faba (L.) plants grown in reclaimed-saline calcareous soil (combined data over 2013/2014 and 2014/2015 seasons).

\begin{tabular}{|c|c|c|c|c|c|}
\hline \multicolumn{2}{|c|}{ Treatments } & \multirow{2}{*}{ Protein } & $\begin{array}{c}\text { Free } \\
\text { proline }\end{array}$ & $\begin{array}{c}\text { Soluble } \\
\text { sugars }\end{array}$ & Starch \\
\hline \multirow{3}{*}{ Variety } & Polyamine & & & & \\
& & & & & \\
\hline \multirow{5}{*}{ Giza 40 } & Control & & & \\
& Spd & $2.57 \pm 0.10 \mathrm{a}^{* *}$ & $197.9 \pm 5.2 \mathrm{~b}$ & $29.5 \pm 1.2 \mathrm{~b}$ & $61.1 \pm 3.7 \mathrm{a}$ \\
& Spm & $2.11 \pm 0.07 \mathrm{~b}$ & $286.5 \pm 8.4 \mathrm{a}$ & $42.0 \pm 2.1 \mathrm{a}$ & $44.9 \pm 2.5 \mathrm{~b}$ \\
& Mean & $\mathbf{2 . 2 7} \pm \mathbf{0 . 0 8 A}$ & $278.4 \pm 8.6 \mathrm{a}$ & $38.9 \pm 2.0 \mathrm{a}$ & $45.3 \pm 2.8 \mathrm{~b}$ \\
& Control & $2.69 \pm 0.09 \mathrm{a}$ & $225.9 \pm 6.0 \mathrm{~b}$ & $33.0 \pm 1.7 \mathrm{~b}$ & $64.3 \pm 3.8 \mathrm{a}$ \\
& Spd & $2.13 \pm 0.06 \mathrm{~b}$ & $314.5 \pm 9.1 \mathrm{a}$ & $46.2 \pm 2.4 \mathrm{a}$ & $41.5 \pm 2.9 \mathrm{~b}$ \\
& Spm & $2.16 \pm 0.06 \mathrm{~b}$ & $308.2 \pm 8.6 \mathrm{a}$ & $44.8 \pm 2.4 \mathrm{a}$ & $42.1 \pm 3.1 \mathrm{~b}$ \\
& Mean & $\mathbf{2 . 3 3} \pm \mathbf{0 . 0 7 A}$ & $\mathbf{2 8 2 . 9} \pm \mathbf{7 . 9 A}$ & $\mathbf{4 1 . 3} \pm \mathbf{2 . 2 A}$ & $\mathbf{4 9 . 3} \pm \mathbf{3 . 3 A}$ \\
\hline
\end{tabular}

"Mean values $(\mathrm{n}=9)$ in the same column for each trait with the same lower small or upper bold-case letters are not significantly different by Duncan's Multiple Range Test at $\mathrm{P} \leq 0.05$.

** Control $=$ seeds soaked in distilled water.

Effect of spermidine (Spd) or spermine (Spm) on malondialdehyde (MDA), ascorbic acid (AsA), glutathione (GSH) and hydrogen peroxide $\left(\mathrm{H}_{2} \mathrm{O}_{2}\right)$ concentrations

For varieties, there are significant increases in the AsA and GSH concentrations and significant decreases in the MDA and $\mathrm{H}_{2} \mathrm{O}_{2}$ concentrations of Giza 429 compared to those of Giza 40. Plants produced from seeds of both varieties which soaked in $1.5 \mathrm{mM}$ spermidine or $1.5 \mathrm{mM}$ spermine showed significant increases in AsA and GSH concentrations, while showed significant decreases in MDA and $\mathrm{H}_{2} \mathrm{O}_{2}$ concentrations compared to control plants that produced from seeds soaked in distilled water (Tables 5 and 6). The increases in the AsA and GSH concentrations were 11.3 and 28.4\%, respectively for Giza 40, and 43.8 and $57.3 \%$, respectively for Giza 429, while the decreases in MDA and $\mathrm{H}_{2} \mathrm{O}_{2}$ concentrations were 36.5 and $34.8 \%$, respectively for Giza 40 and 41 and $37.6 \%$, respectively for Giza 429 compared to their controls. There are no significant differences between the results obtained from Spd and Spm applications. 
TABLE 5. Effect of seed soaking in spermidine (Spd; $1.5 \mathrm{mM}$ ) or spermine (Spm; $1.5 \mathrm{mM}$ ) on leaf contents of non-enzymatic antioxidants [ascorbic acid (nmol ascorbate $\mathrm{g}^{-1} \mathrm{FW}$ ), total glutathione (GSH; nmol GSH $\mathrm{g}^{-1} \mathrm{FW}$ ), Spm (nmol/g FW) and Spd (nmol/g FW)] of two varieties of Vicia faba (L.) plants grown in reclaimed-saline calcareous soil (combined data over 2013/2014 and 2014/2015 seasons).

\begin{tabular}{|c|c|c|c|c|c|}
\hline \multicolumn{2}{|c|}{ Treatments } & Ascorbic & Total GSH & Spm & Spd \\
\cline { 1 - 5 } Variety & Polyamine & acid & & & \\
\hline & Control $^{* * *}$ & $603.5 \pm 10.5 b^{*}$ & $153.3 \pm 5.0 \mathrm{~b}$ & $92.0 \pm 3.8 \mathrm{c}$ & $157.2 \pm 6.1 \mathrm{c}$ \\
Giza 40 & Spd & $671.7 \pm 12.1 \mathrm{a}$ & $196.8 \pm 6.2 \mathrm{a}$ & $102.0 \pm 3.8 \mathrm{~b}$ & $230.1 \pm 9.2 \mathrm{a}$ \\
& Spm & $669.1 \pm 12.2 \mathrm{a}$ & $201.3 \pm 6.4 \mathrm{a}$ & $112.9 \pm 4.9 \mathrm{a}$ & $191.3 \pm 7.8 \mathrm{~b}$ \\
& Mean & $\mathbf{6 4 8 . 1} \pm \mathbf{1 1 . 6 B}$ & $\mathbf{1 8 3 . 8} \pm \mathbf{5 . 9 B}$ & $\mathbf{1 0 2 . 3} \pm \mathbf{4 . 2 B}$ & $\mathbf{1 9 2 . 9} \pm \mathbf{7 . 7 B}$ \\
& Control & $553.5 \pm 10.0 \mathrm{~b}$ & $148.4 \pm 4.1 \mathrm{~b}$ & $85.5 \pm 3.2 \mathrm{c}$ & $165.5 \pm 5.2 \mathrm{c}$ \\
Giza 429 & Spd & $795.9 \pm 14.2 \mathrm{a}$ & $233.5 \pm 6.8 \mathrm{a}$ & $118.3 \pm 5.3 \mathrm{~b}$ & $259.2 \pm 9.6 \mathrm{a}$ \\
& Spm & $781.4 \pm 13.0 \mathrm{a}$ & $244.5 \pm 6.9 \mathrm{a}$ & $142.9 \pm 6.5 \mathrm{a}$ & $202.4 \pm 7.3 \mathrm{~b}$ \\
& Mean & $\mathbf{7 1 0 . 3} \pm \mathbf{1 2 . 4 A}$ & $\mathbf{2 0 8 . 8} \pm \mathbf{5 . 9 A}$ & $\mathbf{1 1 5 . 6} \pm \mathbf{5 . 2 A}$ & $\mathbf{2 0 9 . 0} \pm \mathbf{7 . 4 A}$ \\
\hline
\end{tabular}

"Mean values $(\mathrm{n}=9)$ in the same column for each trait with the same lower small or upper bold-case letters are not significantly different by Duncan's Multiple Range Test at $\mathrm{P} \leq 0.05$.

${ }^{* *}$ Control $=$ seeds soaked in distilled water.

TABLE 6. Effect of seed soaking in spermidine (Spd; $1.5 \mathrm{mM})$ or spermine (Spm; $1.5 \mathrm{mM}$ ) on leaf lipid peroxidation (MDA; in nmol MDA $\mathrm{g}^{-1} \mathrm{FW}$ ) and hydrogen peroxide $\left(\mathrm{H}_{2} \mathrm{O}_{2} ; \mu \mathrm{M} \mathrm{mg}{ }^{-1} \mathrm{FW}\right)$ contents, and shoot contents of sodium $\left(\mathrm{Na}^{+} ; \mathrm{mg} \mathrm{g}^{-1}\right)$ of two varieties of Vicia faba (L.) plants grown in reclaimed-saline calcareous soil (combined data over 2013/2014 and 2014/2015 seasons).

\begin{tabular}{|c|c|c|c|c|}
\hline \multicolumn{2}{|c|}{ Treatments } & \multirow{2}{*}{ MDA } & \multirow{2}{*}{$\mathbf{H}_{2} \mathbf{O}_{\mathbf{2}}$} & Shoot $\mathbf{~ a}^{+}$ \\
\cline { 1 - 2 } Variety & Polyamine & & & \\
\cline { 1 - 2 } Giza 40 & Control $^{* *}$ & $70.2 \pm 3.6 \mathrm{a}^{*}$ & $32.5 \pm 2.1 \mathrm{a}$ & $17.2 \pm 0.4 \mathrm{a}$ \\
& Spd & $44.6 \pm 2.1 \mathrm{~b}$ & $21.2 \pm 1.3 \mathrm{~b}$ & $9.9 \pm 0.2 \mathrm{~b}$ \\
& Spm & $45.2 \pm 2.2 \mathrm{~b}$ & $21.8 \pm 1.4 \mathrm{~b}$ & $10.2 \pm 0.2 \mathrm{~b}$ \\
& Mean & $\mathbf{5 3 . 3} \pm \mathbf{2 . 6 A}$ & $\mathbf{2 5 . 2} \pm \mathbf{1 . 6 A}$ & $\mathbf{1 2 . 4} \pm \mathbf{0 . 3 A}$ \\
& Control $^{* *}$ & $66.8 \pm 3.1 \mathrm{a}$ & $30.3 \pm 2.4 \mathrm{a}$ & $15.5 \pm 0.5 \mathrm{a}$ \\
Giza 429 & Spd & $39.4 \pm 2.0 \mathrm{~b}$ & $18.9 \pm 1.7 \mathrm{~b}$ & $9.2 \pm 0.3 \mathrm{~b}$ \\
& Spm & $40.6 \pm 2.3 \mathrm{~b}$ & $19.5 \pm 1.8 \mathrm{~b}$ & $9.5 \pm 0.3 \mathrm{~b}$ \\
& Mean & $\mathbf{4 8 . 9} \pm \mathbf{2 . 5 B}$ & $\mathbf{2 2 . 9} \pm \mathbf{2 . 0 B}$ & $\mathbf{1 1 . 4} \pm \mathbf{0 . 4 B}$ \\
\hline
\end{tabular}

"Mean values $(n=9)$ in the same column for each trait with the same lower small or upper bold-case letters are not significantly different by Duncan's Multiple Range Test at $\mathrm{P} \leq 0.05$.

${ }^{* *}$ Control $=$ seeds soaked in distilled water.

Effect of spermidine (Spd) or spermine (Spm) on leaf Spd and Spm and shoot sodium $\left(\mathrm{Na}^{+}\right)$concentrations

For varieties, there are significant increases in endogenous Spd and Spm concentrations and significant decreases in $\mathrm{Na}^{+}$concentration in Giza 429 compared to those in Giza 40. Soaking the seeds of both varieties in $1.5 \mathrm{mM}$ Spd or $1.5 \mathrm{mM} \mathrm{Spm} \mathrm{significantly} \mathrm{increased} \mathrm{the} \mathrm{concentrations} \mathrm{of} \mathrm{endogenous}$ Spd and Spm. In addition, each polyamine increased itself significantly 
compared to other polyamine. In contrast, Spd or Spm application as seed soaking significantly reduced shoot $\mathrm{Na}^{+}$concentration compared to the control (Tables 5 and 6). The increases in the endogenous Spd and Spm were 22.7 and $46.4 \%$, respectively for Giza 40 and were 67.1 and $56.6 \%$, respectively for Giza 429 compared to the control. The reduction in $\mathrm{Na}^{+}$concentration was $42.4 \%$ for Giza 40 and was $40.6 \%$ for Giza 429 . There are no significant differences between the results obtained from Spd and Spm applications.

Effect of spermidine (Spd) or spermine (Spm) on antioxidant enzyme activities

For varieties, there are significant increases in the activities of all tested enzymes in Giza 429 compared to those of Giza 40. Soaking the seeds of both varieties in $1.5 \mathrm{mM}$ spermidine or $1.5 \mathrm{mM}$ spermine significantly increased the activities of all tested antioxidant enzymes (i.e., superoxide dismutase; SOD, catalase; CAT, peroxidase; POX and ascorbate peroxidase; APX) of plants compared to control plants that generated from seeds soaked in distilled water (Table 7). The increases in the above enzymatic antioxidants were 52.6, 27.3, 78.5 and 79.1\%, respectively for Giza 40, and were 45.6, 49, 79 and 69.2\%, respectively for Giza 429 compared to their controls. There are no significant differences between the results obtained from Spd and Spm applications.

TABLE 7. Effect of seed soaking in spermidine (Spd; $1.5 \mathrm{mM}$ ) or spermine (Spm; 1.5 $\mathrm{mM}$ ) on the activities of enzymatic antioxidants [superoxide dismutase (SOD; Units $\mathrm{g}^{-1} \mathrm{FW}$ ), catalase (CAT; $\mu$ kat $\mathrm{mg}^{-1}$ protein $\min ^{-1}$ ), peroxidase (POX; Unit $\mathrm{mg}^{-1}$ protein $\mathrm{min}^{-1}$ ), and ascorbate peroxidase (APX; Unit $\mathrm{mg}^{-1}$ protein $\mathrm{min}^{-1}$ )] in leaves of two varieties of Vicia faba (L.) plants grown in reclaimed-saline calcareous soil (combined data over 2013/2014 and 2014/2015 seasons).

\begin{tabular}{|c|c|c|c|c|c|}
\hline \multicolumn{2}{|c|}{ Treatments } & \multirow{2}{*}{ SOD } & CAT & POX & APX \\
\cline { 1 - 5 } Variety & Polyamine & & & & \\
\hline \multirow{4}{*}{ Giza 40 } & Control $^{* *}$ & $171 \pm 6 b^{*}$ & $9.9 \pm 0.2 \mathrm{~b}$ & $0.93 \pm 0.04 \mathrm{~b}$ & $11.5 \pm 0.4 \mathrm{~b}$ \\
& Spd & $261 \pm 9 \mathrm{a}$ & $12.6 \pm 0.3 \mathrm{a}$ & $1.66 \pm 0.06 \mathrm{a}$ & $20.6 \pm 0.7 \mathrm{a}$ \\
& Spm & $255 \pm 8 \mathrm{a}$ & $12.3 \pm 0.3 \mathrm{a}$ & $1.63 \pm 0.06 \mathrm{a}$ & $20.1 \pm 0.7 \mathrm{a}$ \\
& Mean & $\mathbf{2 2 9} \pm \mathbf{8 B}$ & $\mathbf{1 1 . 6} \pm \mathbf{0 . 3 B}$ & $\mathbf{1 . 4 1} \pm \mathbf{0 . 0 5 B}$ & $\mathbf{1 7 . 4} \pm \mathbf{0 . 6 B}$ \\
& Control & $195 \pm 7 \mathrm{~b}$ & $10.0 \pm 0.4 \mathrm{~b}$ & $1.00 \pm 0.07 \mathrm{~b}$ & $13.3 \pm 0.5 \mathrm{~b}$ \\
Giza 429 & Spd & $284 \pm 10 \mathrm{a}$ & $14.9 \pm 0.5 \mathrm{a}$ & $1.79 \pm 0.09 \mathrm{a}$ & $22.5 \pm 0.8 \mathrm{a}$ \\
& Spm & $275 \pm 9 \mathrm{a}$ & $14.1 \pm 0.5 \mathrm{a}$ & $1.73 \pm 0.09 \mathrm{a}$ & $22.1 \pm 0.8 \mathrm{a}$ \\
& Mean & $\mathbf{2 5 1} \pm \mathbf{9 A}$ & $\mathbf{1 3 . 0} \pm \mathbf{0 . 5 A}$ & $\mathbf{1 . 5 1} \pm \mathbf{0 . 0 8 A}$ & $\mathbf{1 9 . 3} \pm \mathbf{0 . 7 A}$ \\
\hline
\end{tabular}

"Mean values $(\mathrm{n}=9)$ in the same column for each trait with the same lower small or upper bold-case letters are not significantly different by Duncan's Multiple Range Test at $\mathrm{P} \leq 0.05$.

${ }^{* *}$ Control $=$ seeds soaked in distilled water.

Effect of spermidine (Spd) or spermine (Spm) on yield and its components

For varieties, there are significant increases in the yield and its components (i.e., number of dry pods plant ${ }^{-1}, 100$-seed weight, dry seed yield plant ${ }^{-1}$ and dry seed yield hectare ${ }^{-1}$ ) of Giza 429 compared to those of Giza 40. Soaking the seeds of both varieties in $1.5 \mathrm{mM}$ Spd or $1.5 \mathrm{mM} \mathrm{Spm}$ significantly increased the yield and its components of plants compared to control plants that generated from seeds soaked in distilled water (Table 8). The increases in the yield and its Egypt. J. Agron. 38, No. 1 (2016) 
components were $62.5,35.7,48.7$ and $66.3 \%$, respectively for Giza 40, and were $53.9,47.4,51.5$ and $62.5 \%$, respectively for Giza 429 compared to their controls. There are no significant differences between the results obtained from Spd and Spm applications.

TABLE 8. Effect of seed soaking in spermidine (Spd) or spermine (Spm) on the yield and its components of two varieties of Vicia faba (L.) plants grown in reclaimed-saline calcareous soil (combined data over 2013/2014 and 2014/2015 seasons).

\begin{tabular}{|c|c|c|c|c|c|}
\hline \multicolumn{2}{|c|}{ Treatments } & \multirow{2}{*}{$\begin{array}{l}\text { No. of dry } \\
\text { pods } \\
\text { plant }^{-1}\end{array}$} & \multirow{2}{*}{$\begin{array}{l}\text { 100-seed } \\
\text { weight } \\
\text { (g) }\end{array}$} & \multirow{2}{*}{$\begin{array}{c}\text { Dry seed } \\
\text { yield plant }{ }^{-1} \\
(\mathrm{~g})\end{array}$} & \multirow{2}{*}{$\begin{array}{l}\text { Dry seed } \\
\text { yield } \\
\text { hectare }^{-1} \\
\text { (ton) }\end{array}$} \\
\hline Variety & Polyamine & & & & \\
\hline \multirow{4}{*}{ Giza 40} & Control $^{* * *}$ & $15.2 \pm 0.7 b^{*}$ & $55.7 \pm 2.5 b$ & $39.4 \pm 2.1 \mathrm{~b}$ & $1.72 \pm 0.13 b$ \\
\hline & Spd & $24.7 \pm 1.2 \mathrm{a}$ & $75.6 \pm 3.1 \mathrm{a}$ & $58.6 \pm 3.9 \mathrm{a}$ & $2.86 \pm 0.21 \mathrm{a}$ \\
\hline & Spm & $24.3 \pm 1.2 \mathrm{a}$ & $74.1 \pm 3.0 \mathrm{a}$ & $56.9 \pm 3.5 \mathrm{a}$ & $2.79 \pm 0.20 \mathrm{a}$ \\
\hline & Mean & $21.4 \pm 1.0 \mathrm{~B}$ & $68.5 \pm 2.9 \mathrm{~B}$ & $51.6 \pm 3.3 B$ & $2.46 \pm 0.18 B$ \\
\hline \multirow{4}{*}{ Giza 429} & Control. & $17.8 \pm 0.9 b$ & $57.8 \pm 2.6 b$ & $43.1 \pm 2.4 b$ & $1.92 \pm 0.14 b$ \\
\hline & Spd & $27.4 \pm 1.5 \mathrm{a}$ & $85.2 \pm 3.3 \mathrm{a}$ & $65.3 \pm 4.0 \mathrm{a}$ & $3.12 \pm 0.26 \mathrm{a}$ \\
\hline & Spm & $27.2 \pm 1.4 \mathrm{a}$ & $83.4 \pm 3.1 \mathrm{a}$ & $64.6 \pm 3.9 \mathrm{a}$ & $3.07 \pm 0.24 \mathrm{a}$ \\
\hline & Mean & $24.1 \pm 1.3 A$ & $75.5 \pm 3.0 \mathrm{~A}$ & $57.7 \pm 3.4 A$ & $2.70 \pm 0.21 \mathrm{~A}$ \\
\hline
\end{tabular}

"Mean values $(\mathrm{n}=9)$ in the same column for each trait with the same lower small or upper bold-case letters are not significantly different by Duncan's Multiple Range Test at $\mathrm{P} \leq 0.05$.

${ }^{* *}$ Control $=$ seeds soaked in distilled water.

\section{Discussion}

Our results showed that growth attributes of faba bean plants reduced under soil salinity. Under soil salinity stress, faba bean plants cannot continue to grow well. So, we chose to focus on the use of the selected suitable level of each polyamine that gives the best improves on recovery saline effect on faba bean plants. Exogenous application of spemidine (Spd) or spermine (Spm) as seed soaking markedly resulted in alleviating the negative effects of salt stress and improving the growth characteristics of faba bean plants (Table 2). These improved growth characteristics have been found to increase the seed yield and its components (Table 8).

The data of the current study indicate that exogenous pretreatment of Spd or Spm was shown to stabilize plant cell membranes, protecting them from damage due to salt stress. In addition, each of polyamines (PAs) maintained cells in a turgid status and reduced ion leakage from cells (Table 3). Borell et al. (1997) suggested that these positive findings may be attributed to the increase in the endogenous Spd or Spm (Table 5), which are suggested to participate in sustaining membrane integrity.

In this study, the activities of antioxidant enzymes (i.e., SOD, CAT, POX and APX) significantly increased in faba bean plants when grown under soil salinity stress. This result confirms the finding of Parida \& Das (2005) in regard to the 
mutual relationship between higher antioxidant activity and salinity tolerance. Exogenous pretreatment (seed soaking) of Spd or Spm caused to increase the activities of POX, APX, SOD and CAT. Each of the PAs can regulate many enzyme activities by bonding with the enzyme protein or participation in the process of phosphorylation of the enzyme protein (Stark et al., 2011). The SOD enzyme is the first defence against superoxide $\left(\mathrm{O}_{2}^{-}\right)$radicals, found to catalyze the conversion of $\mathrm{O}_{2}^{-}$to $\mathrm{H}_{2} \mathrm{O}_{2}$ that is subsequently reduced to $\mathrm{H}_{2} \mathrm{O}$ by $\mathrm{POX}$ (Alscher et al., 2002) using several reductants, including AsA and GSH (Apel \& Hirt, 2004). Further, CAT also scavenges $\mathrm{H}_{2} \mathrm{O}_{2}$ by converting it to $\mathrm{H}_{2} \mathrm{O}$ and finally $\mathrm{O}_{2}$.

The reduction in the activity of $\mathrm{H}_{2} \mathrm{O}_{2}$ was also another result of the pretreatment of Spd or Spm for faba bean plants. The $\mathrm{H}_{2} \mathrm{O}_{2}$ is one of the major and most stable ROS and its high concentration leads to oxidative stress through the increase in the lipid peroxidation and the reduction in membrane stability index (Upchurch, 2008 and Dionisio-Sesc \& Tobita, 1998).

Each of PAs (Spd or Spm) was observed to negate oxidative injury in plants by acting as direct free radical scavengers (Bors et al., 1989). Therefore, the increased activities of SOD, CAT, POX and APX against ROS seem to be one of the mechanisms in which seed soaking in Spd or Spm found to alleviate salt stress in faba bean plants. The results of this study showed a more important role, to some extent, of Spd than Spm in alleviating salt stress in faba bean plants. This might be attributed to the increased endogenous concentrations of Spd than Spm in faba bean plants (Table 5).

However, many contrasting reports have suggested the change in PAs under salt stress conditions to be a protective mechanism (Kasukabe et al., 2004 and Iqbal et al., 2006). In the current study, salt stress caused a reduction in the concentration of protein in faba bean plants which confirms the finding of Sharma \& Dubey (2010), and pretreatment of Spd or Spm increased protein concentration. Furthermore, production of free radicals such as $\mathrm{H}_{2} \mathrm{O}_{2}$ under salt stress conjugates to proteins, and consequently destruction in their structures (Peltzer et al., 2002). Therefore, the positive influence of Spd or Spm might be due to either preventing the production of free radicals or free radicals scavenging mechanisms, thereafter protecting protein levels.

Under salt stress, soluble sugars tend to increase while starch concentration decreases (Chaves et al., 2009), which is in agreement with our findings. Photosynthesis is the most important phenomenon inhibited under the stress resulting in reducing the whole produced starch and soluble sugars within the seedlings (Demetriou et al., 2007). The modulation of Spd or Spm in reducing the concentration of soluble sugars and increasing the concentration of starch in faba bean plants under salt stress might be due to the constructive roles of Spd and Spm in improving and maintaining the structure and function of photosynthetic system during salinity stress.

Egypt. J. Agron. 38, No. 1 (2016) 
Our results showed also that under soil salinity stress, the proline concentration in faba bean plants was increased. In this concern, Zhu (2001) reported that plants accumulate compatible osmolytes such as proline when they are subjected to salinity stress. In addition, proline probably detoxifies plants by scavenging ROS or prevents them from damaging cellular structures. There is strong evidence that proline as an amino acid play an adaptive role in mediating osmotic adjustment and protecting the subcellular structures in stressed plants (Ashraf \& Harris, 2004). In our study, Spd or Spm caused to increase the content of proline in faba bean plants showing a mechanism with other mechanisms by which Spd or Spm reduces the negative impact of soil salinity stress, increasing the faba bean yields.

Data of the present study also show that, the variety Giza 429 exhibited better growth characteristics, water relations, antioxidants (enzymatics and nonenzymatics), polyamines, pod and seed yields than the variety Giza 40, concluding that Giza 429 was more salt-tolerant compared to Giza 40.

More work is necessary to find exactly the protecting roles of these PAs (i.e., Spd and Spm) on photosynthetic systems under salt stress, to provide potential new mechanisms of a plant's tolerance to salinity stress, and to define the physiological roles of Spd and Spm in relation to salinity stress.

\section{Conclusion}

Among the PAs, Spd or Spm are beneficial to cope with salt stress, but additional studies are needed to separate the best effectiveness of these two PAs as well as their concentrations. Results of this study demonstrate that Spd or Spm reduced the soil salinity stress by increasing the activities of SOD, CAT, POX and APX and reducing the levels of $\mathrm{H}_{2} \mathrm{O}_{2}$. Indeed, Spd or Spm has shown to effectively protect the faba bean plants against the adverse effects of salt stress, at least partially by protecting proteins and carbohydrates against ROS and positively altering the antioxidant system in plants. Exogenous application of Spd or Spm as a seed soaking solution might be recommended as an effective technique for improving the tolerance of faba bean plants, especially the variety Giza 429 under salinity stress.

Acknowledgment : Above all, I would like to prostrate for God, who gave patient and made our work successful. The author would like to thank Prof. Dr. Mostafa M. Rady, Professor of Plant Physiology, Botany Department, Faculty of Agriculture, Fayoum University for his valuable guidance and assistance for enzyme and antioxidant assays, and also for the determinations of lipid peroxidation and tissue water and ion relations. 


\section{References}

Alca'zar, R., Altabella, T., Marco, F., Bortolotti, C., Reymond, M., Koncz, C., Carrasco, P. and Tiburcio, A. (2010) Polyamines: molecules with regulatory functions in plant abiotic stress tolerance. Planta, 231, 1237-1249.

Alscher, P.G., Erturk, N. and Heath, L.S. (2002) Role of superoxide dismutases (SODs) in controlling oxidative stress in plant. Journal of Experimental Botany, 53, 1331-1341.

Amri, E., Mirzaei, M., Moradi, M. and Zare, K. (2011) The effect of spermidine and putrescine polyamine on growth of pomegranate (Punica granatum) in salinity circumstance. International Journal of Plant Physiology and Biochemistry, 3, 43-49.

An, Z.F., Li, C.Y., Zhang, L.X. and Alva, A.K. (2012) Role of polyamines and phospholipase D in maize (Zea mays L.) response to drought stress. South African Journal of Botany, 83, 145-150.

Apel, K. and Hirt, H. (2004) Reactive oxygen species: Metabolism oxidatives and signal transduction. Annual Review of Plant Physiology and Plant Molecular Biology, 55, 373-399.

Ashraf, M. and Harris, P.J.C. (2004) Potential biochemical indicators of salinity tolerance in plants. Plant Science, 166, 3-16.

Bates, L.S., Waldren, R.P. and Teare, I.D. (1973) Rapid determination of free proline for water stress studies. Plant and Soil, 39, 205-207.

Bethkey, P.C. and Drew, M.C. (1992) Stomatal and non-stomatal components to inhibition of photosynthesis in leaves of Capsicum annum during progressive exposure to $\mathrm{NaCl}$ salinity. Plant Physiology, 99, 219-226.

Borell, A., Carbonell, L., Farras, R., Puig-Parellada, P. and Tiburcio, A.F. (1997) Polyamines inhibit lipid peroxidation in senescing oat leaves. Physiologia Plantarum, 99, 385-90.

Bors, W., Langebartels, C., Michael, C. and Sandermann, H. (1989) Polyamines as radical scavengers and protectants against ozone damage. Phytochemistry, 28, 15891595.

Bouchereau, A., Aziz, A., Larher, F. and Martin-Tanguy, J. (1999) Polyamines and environmental challenges: Recent development. Plant Science, 140, 103-125.

Bradford, M.N. (1979) A rapid and sensitive method for the quantitation of microgram quantities of protein utilizing the principles of protein-dye binding. Analytical Biochemistry, 72, 248-254.

Broughton, W.J., Hernandez, G., Blair, M., Beebe, S., Gepts, P. and Vanderleyden, J. (2003) Beans (Phaseolus spp.) - model food legumes. Plant and Soil, 252, 55-128. 
Cakmak, I. and Marschner, H. (1992) Magnesium deficiency and high light intensity enhance activities of superoxide dismutase, ascorbate peroxidase, and glutathione reductase in bean leaves. Plant Physiology, 98, 1222-1227.

Chaves, M.M., Flexas, J. and Pinheiro, C. (2009) Photosynthesis under drought and salt stress: Regulation mechanisms from whole plant to cell. Annals of Botany, 103, 551560.

Dahnke, W.C. and Whitney, D.A. (1988) Measurement of soil salinity. In: "Recommended Chemical Soil Test Procedures for the North Central Region". Dahnke, W.C. (Ed.), pp. 32-34. North Dakota Agric. Exp. St. Bulletin. 499. North Central Reg. Publ. 221.

Delgado, M.J., Ligero, F. and Lluch, C. (1994) Effects of salt stress on growth and nitrogen fixation by pea, faba bean, common bean, and soybean plants. Soil Biol. Biochem, 26, 371-376.

Demetriou, G., Neonaki, C., Navakoudis, E. and Kotzabasis, K. (2007) Salt stress impact on the molecular structure and function of the photosynthetic apparatusthe protective role of polyamines. BBA-Bioenergetics, 1767, 272-280.

Dionisio-Sesc, L.M. and Tobita, S. (1998) Antioxidant response of rice seedling to salinity stress. Plant Science, 35, 1-9.

Duan, J., Li, J., Guo, S. and Kang, Y. (2008) Exogenous spermidine affects polyamine metabolism in salinity stressed Cucumis sativus roots and enhances short-termsalinity tolerance. Journal of Plant Physiology, 165, 1620-1635.

Gaballah, M.S. and Gomaa, A.M. (2005) Interactive effect of rhizobium inoculation, sodium benzoate and salinity on performance and oxidative stress in two faba bean varieties. International Journal of Agriculture \& Biology, 7(3), 495-498.

Galston, A.W., Kaur-Sawhney, R., Altabella, T. and Tiburcio, A.F. (1997) Plant polyamines in reproductive activity and response to abiotic stress. Botanica Acta, 110, 197-207.

Gomez, K.A. and Gomez, A.A. (1984) "Statistical Procedures for Agricultural Research", $2^{\text {nd }}$ ed. John Wiley \& Sons, Singapore. p.680.

Giannopolitis, C.N. and Ries, S.K., (1977) Superoxide dismutases. I. Occurrence in higher plants. Plant Physiology, 59, 309-314.

Griffth, O.W. (1980) Determination of glutathione and glutathione disulfide using glutathione reductase and 2 vinyl pyridine. Analytical Biochemistry, 106, 207-212.

Hayat, S., Ali, B., Hasan, S.A. and Ahmad, A. (2007) Brassinosteroid enhanced the level of antioxidants under cadmium stress in Brassica juncea. Environmental and Experimental Botany, 60, 33-41.

Hedge, J.E. and Hofreiter, B.T. (1962) Estimation of starch by anthrone reagent. In: "Methods in Carbohydrate Chemistry". Whistler, R.L., Be-Miller, J.N. (Ed.). Academic Press, New York. 
Hodges, M.D., Delong, J.M., Forney, C.F. and Prange, R.K. (1999) Improving the thiobarbituric acid-reactive-substances assay for lipid peroxidation in plant tissues containing anthocyanin and other interfering compounds. Planta, 207, 604-611.

Iqbal, M., Ashraf, M., Rehman, S. and Rha, E.S. (2006) Does polyamine seed pretreatment modulate growth and levels of some plant growth regulators in hexaploid wheat (Triticum aestivum L.) plants under salt stress? Botanical Studies, 47, 239-250.

Irigoyen, J.J., Emerich, D.W. and Sanchez-Diaz, M. (1992) Water stress induced changes in the concentrations of proline and total soluble sugers in nodulated alfalfa (Medicago sativa) plants. Physiologia Plantarum, 8, 455-460.

Janicka-Russak, M.L., Kabala, K.K., Mlodzinska, E. and Klobus, G. (2010) The role of polyamines in the regulation of the plasma membrane and the tonoplast proton pumps under salt stress. Journal of Plant Physiology, 167, 261-269.

Kara, M. and Mishra, D. (1976) Catalase, peroxidase, polyphenoloxidase activities during rice leaf senescence. Plant Physiology, 57, 315-319.

Kasukabe, Y., He, L., Nada, K., Misawa, S., Ihara, I. and Tachibana, S. (2004) Overexpression of spermidine synthase enhances tolerance to multiple environmental stresses and up-regulates the expression of various stress-regulated genes in transgenic Arabidopsis thaliana. Plant and Cell Physiology, 45, 712-722.

Kim, T.E., Kim, S.K., Han, T.J., Lee, J.S. and Chang, S.C. (2002) ABA and polyamines act independently in primary leaves of cold-stressed tomato (Lycopersicon esculentum). Physiologia Plantarum, 115, 370-376.

Klute, A. (1986) "Methods of Soil Analysis. Part I: Physical and Mineralogical Methods" $\left(2^{\text {nd }} \mathrm{ed}\right)$. American Society of Agronomy Madison, Wisconsin, USA, xxviii., $1188 \mathrm{pp}$.

Lopatin, A.N., Makhina, E.N. and Nichols, C.G. (1994) Potassium channel block by cytoplasmic polyamines as the mechanism of intrinsic rectification. Nature, 372, 366369.

Mass, E.V. and Hoffman, G.J. (1977) Crop salt tolerance - current assessment. Journal of Irrigation and Drainage, 103, 115-134.

Mukherjee, S.P. and Choudhuri, M.A. (1983) Implications of water stress induced changes in the levels of endogenous ascorbic acid and hydrogen peroxide in Vigna seedlings. Physiologia Plantarum, 58, 166-170.

Munns, R. (2002) Comparative physiology of salt and water stress. Plant Cell and Environment, 25, 239-250.

Nakano, Y. and Asada, K. (1981) Hydrogen peroxide is scavenged by ascorbateperoxidase in spinach chloroplast. Plant and Cell Physiology, 22, 867-880.

Neumann, P. (1997) Salinity resistance and plant growth revisited. Plant Cell and Environment, 20, 1193-1198.

Egypt. J. Agron. 38, No. 1 (2016) 
Noble, C.L. and Rogers, M.E. (1992) Arguments for the use of physiological criteria for improving the salt tolerance in crops. Plant and Soil, 146, 99-107.

Page, A.I., Miller, R.H. and Keeney, D.R., (1982) "Methods of Soil Analysis. Part II: Chemical and Microbiological Properties" ( $2^{\text {nd }}$ edition). American Society of Agronomy Madison, Wisconsin, USA, pp. 225-246.

Pandolfi, C., Pottosin, I., Cuin, T., Mancuso, S. and Shabala, S. (2010) Specificity of polyamine effects on $\mathrm{NaCl}$-induced ion flux kinetics and salt stress amelioration in plants. Plant and Cell Physiology, 51, 422-434.

Parida, A.K. and Das, A.B. (2005) Salt tolerance and salinity effects on plants. Ecotoxicology and Environmental Safety, 60,324-349.

Peltzer, D., Dreyer, E. and Polle, A. (2002) Differential temperature dependencies of antioxidative enzymes in two contrasting species. Plant Physiology and Biochemistry, 40, 141-150.

Rady, M.M. (2011) Effect of 24-epibrassinolide on growth, yield, antioxidant system and cadmium content of bean (Phaseolus vulgaris L.) plants under salinity and cadmium stress. Scientia Horticulturae, 129, 232-237.

Rady, M.M., Bhavya Varma, C. and Howladar, S.M. (2013) Common bean (Phaseolus vulgaris L.) seedlings overcome $\mathrm{NaCl}$ stressas a result of presoaking in Moringa oleifera leaf extract. Scientia Horticulturae, 162, 63-70.

Sairam, R.K., Srivastava, G.C., Agarwal, S. and Meena, R.C. (2005) Differences in antioxidant activity in response to salinity stress in tolerant and susceptible wheat genotypes. Biologia Plantarum, 49, 85-91.

Saxena, N.P., Johansen, C., Saxena,M.C. and Silim, S.N. (1993) Selection for drought and salinity tolerance in cool-season food legumes. In: "Breeding for Stress Tolerance in Cool-Season Food Legumes". Singh, K.B., Saxena, M.C. (Ed.), pp.245-270. John Wiley \& Sons, New York.

Sharma, P. and Dubey, R.S. (2010) Protein synthesis by plants under stressful conditions. In: "Handbook of Plant and Crop Stress". Pessarakli, M. (Ed.). pp. 465518. CRC Press, Boca Raton,

Soussi, M., Ocand, A. and Lluch, C. (1998) Effect of salt stress on growth, photosynthesis and nitrogen fixation in chickpea (Cicer arietinum L.). Journal of Experimental Botany, 49, 1329-1337.

Stark, F., Pfannstiel, J., Klaiber, I. and Raabe, T. (2011) Protein kinase $\mathrm{CK}_{2}$ links polyamine metabolism to MAPK signaling in Drosophila. Cellular Signaling, 23, 876-882.

Subbarao, G.V. and Johansen, C.J. (1993) Potential for genetic improvement in salinity tolerance in legumes. In: "Handbook of Plant and Crop Stress". Pessarakli, M. (Ed.), pp. 581-591. Marcel Dekker, New York. 
Sudhir, P. and Murthy, S.D.S. (2004) Effect of salt stress on basic process of photosynthesis. Photosynthetica, 42, 481-486.

Sullivan, C.Y. and Ross, W.M. (1979) Selecting the drought and heat resistance in grain sorghum. In: "Stress Physiology in Crop Plants". Mussel, H., Staples, R.C. (Ed.), pp. 263-281. John Wiley \& Sons, New York.

Taleisnik, E. and Grunberg, K. (1994) Ion balance in tomato cultivars differing in salt tolerance. I. Sodium and potassium accumulation and fluxes under moderate salinity. Physiologia Plantarum, 92, 528-534.

Upchurch, R.G. (2008) Fatty acid unsaturation, mobilization and regulation in response of stress to plants. Biotechnology Letters, 30, 967-977.

Velikova, V., Yordancv, I. and Edreva, A. (2000) Oxidative stress and some antioxidant systems in acid rain-treated bean plants. Protective role of exogenous polyamines. Plant Science, 151, 59-66.

Verma, S. and Mishra, S.N. (2005) Putrescine alleviation of growth in salt stressed Brassica juncea by inducing antioxidative defense system. Journal of Plant Physiology, 62, 669-677.

Zhu, J.K. (2001) Plant salt tolerance. Trends in Plant Science, 6, 66-71.

(Received 24/12/2015;

accepted 25/2/2016) 


\section{تحسين تحمل نباتات الفول البلاي للملوحة باستخدام البولي أمينات}

$$
\text { قايمن حمدي علي مهاى الزيل اعة - جامعة الفيوم - الفيوم - مصر. }
$$

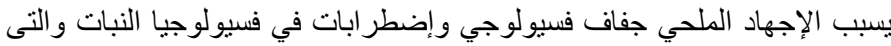

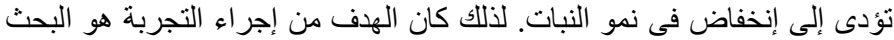

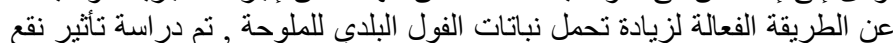

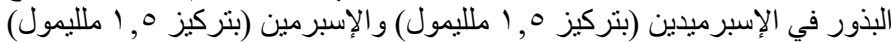

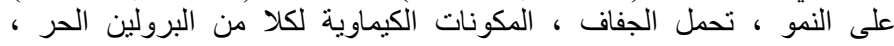

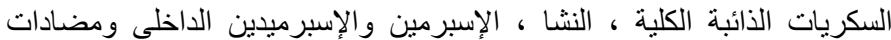

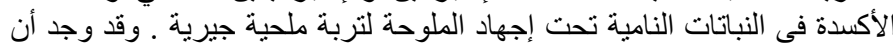

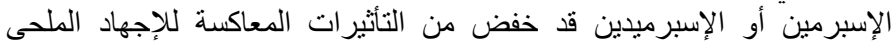

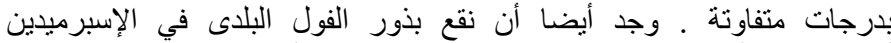

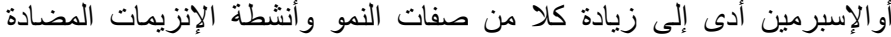

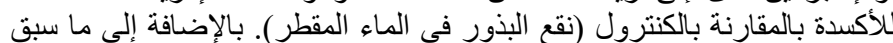

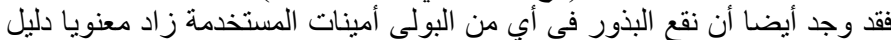

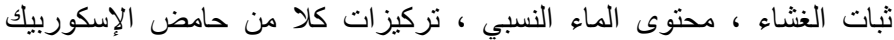

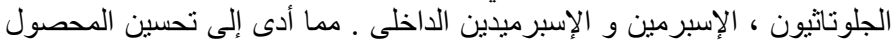

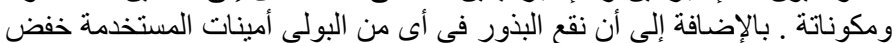

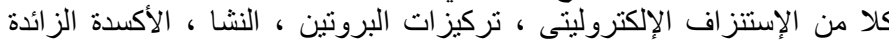

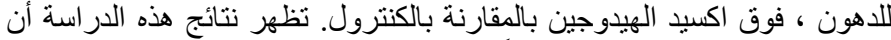

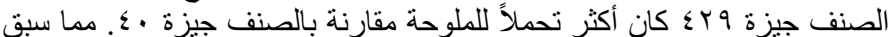

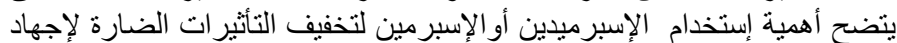
ملوحة التربة ولزيادة تحمل نباتات الفول البلدى لتلكئك الظروف الإنب المعاكسة. 